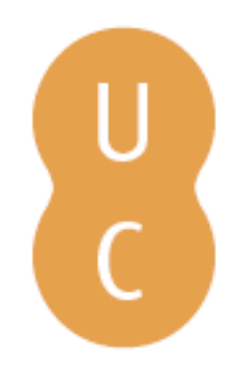

\title{
nommalina
}

\section{Changing fire regimes: The response of litter-dwelling invertebrates to altered seasonality and frequency of fire}

\author{
Autor(es): $\quad$ York, Alan \\ Publicado por: Imprensa da Universidade de Coimbra \\ URL \\ persistente: URI:http://hdl.handle.net/10316.2/34164 \\ DOI: $\quad$ DOI:http://dx.doi.org/10.14195/978-989-26-0884-6_59 \\ Accessed : $\quad$ 26-Apr-2023 05:53:20
}

A navegação consulta e descarregamento dos títulos inseridos nas Bibliotecas Digitais UC Digitalis, UC Pombalina e UC Impactum, pressupõem a aceitação plena e sem reservas dos Termos e Condições de Uso destas Bibliotecas Digitais, disponíveis em https://digitalis.uc.pt/pt-pt/termos.

Conforme exposto nos referidos Termos e Condições de Uso, o descarregamento de títulos de acesso restrito requer uma licença válida de autorização devendo o utilizador aceder ao(s) documento(s) a partir de um endereço de IP da instituição detentora da supramencionada licença.

Ao utilizador é apenas permitido o descarregamento para uso pessoal, pelo que o emprego do(s) título(s) descarregado(s) para outro fim, designadamente comercial, carece de autorização do respetivo autor ou editor da obra.

Na medida em que todas as obras da UC Digitalis se encontram protegidas pelo Código do Direito de Autor e Direitos Conexos e demais legislação aplicável, toda a cópia, parcial ou total, deste documento, nos casos em que é legalmente admitida, deverá conter ou fazer-se acompanhar por este aviso.

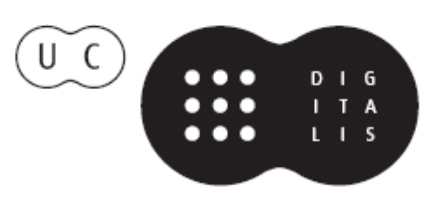




\section{ADVANCES IN}

Forest Fire

\section{RESEARCH}

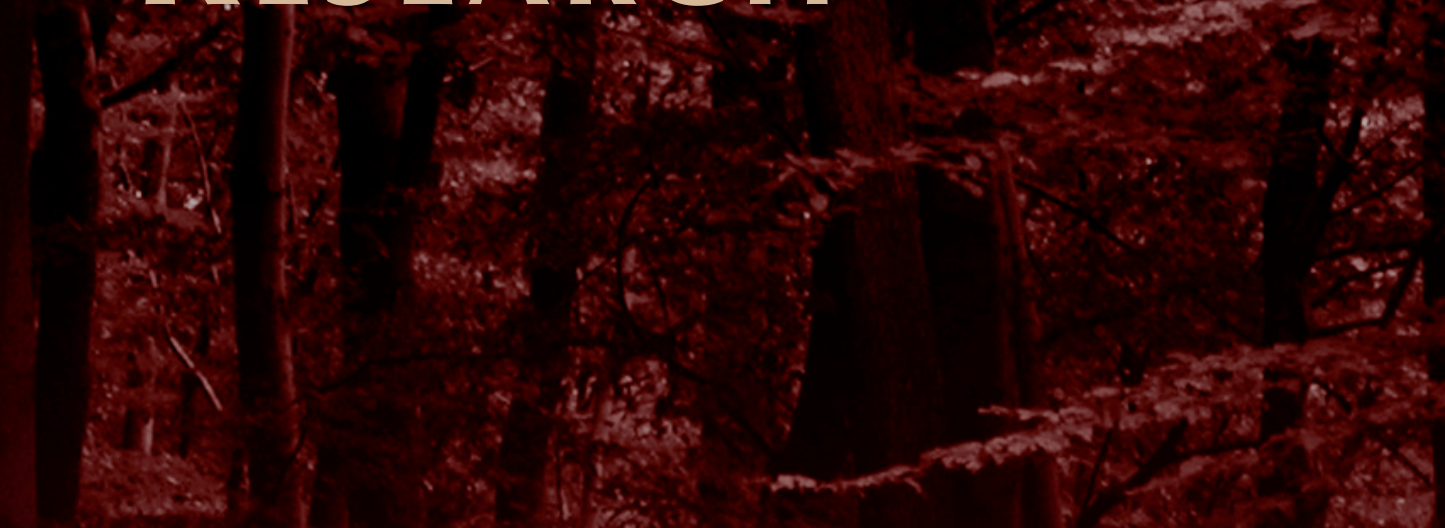

\section{DOMINGOS XAVIER VIEGAS}

\section{EDITOR}




\title{
Changing fire regimes: The response of litter-dwelling invertebrates to altered seasonality and frequency of fire
}

\author{
Alan York \\ University of Melbourne, 4 Water Street CreswickVIC 3363 Australia, alan.york@ unimelb.edu.au
}

\begin{abstract}
Mediterranean climate regions are experiencing changes that are projected to have significant impacts on patterns of temperature and rainfall, thereby affecting key ecosystem drivers such as fire regimes. In the sclerophyll-dominated vegetation communities of southern Australia, land managers are responding to increased wildfire probabilities through the use of more frequent low intensity (prescribed) fire. With burning occurring more often throughout the year, plant and animal communities are experiencing altered fire regimes; with changes to both frequency and season of burn. Here I report on the results of a long-term, replicated study, investigating the effects of fire frequency (high vs low) and seasonality (autumn vs spring) on a biodiverse and functionally important component of the fauna (litter-dwelling invertebrates). At the ordinal level, three broad patterns of response were detected: (i) no effect of fire treatment on abundance, (ii) a burning treatment effect, suggesting that fire in any season and at any frequency lowers abundance, and (iii) a significant negative effect of fire frequency on abundance. No season of fire effects were apparent for any group. The mechanisms underpinning these responses warrant further investigation, particularly in light of proposed increases in the amount of prescribed fire to be applied to these forest systems in coming years.
\end{abstract}

Keywords: climate change, fire regime, invertebrates, prescribed fire

\section{Introduction}

The application of prescribed fire in many regions is becoming more common amid forecasted increases in the frequency and severity of wildfire under climate change (Stephens et al. 2012; Cary et al. 2012; Flannigan et al. 2013). For example, in the state of Victoria in south-eastern Australia, a long term program of prescribed burning on an annual rolling target of $5 \%$ of public land (equating to a minimum of 385,000 ha per year) was introduced following severe wildfires in 2009 (Attiwill and Adams 2013). Historically, primarily for safety reasons, prescribed burning in these temperate ecosystems has been undertaken during autumn (Luke and McArthur 1978), however to meet new burn targets managers are now applying fire whenever weather conditions allow. As a consequence prescribed fires are occurring across a broader range of seasons and, potentially, with increased frequency (i.e. reduced intervals between successive burns). Understanding the implications of such changes in the fire regime for biodiversity is therefore critical (Bradstock et al. 2010; Penman et al. 2011).

As a group, invertebrates are numerous, diverse, and play important functional roles in ecosystems (Beattie 1995; Raven and Yeates 2007). Through their role in the breakdown and decomposition of organic matter and the release of materials to the soil environment, invertebrates have a positive influence on the availability of nutrients for plant growth and on soil physical properties. In Australia there have been a number of studies on the effects of low-intensity prescribed fire on invertebrates, particularly in regard to the interval between such fires (fire frequency); with fewer examining the season of burn. Following two short rotation (three-year interval) low-intensity fires in spring in Victoria, Collett et al. (2003) found that arthropod diversity had increased following the second fire, caused by greater evenness of individuals among taxa rather than any change in taxon richness. Three fires over an eight-year period had no cumulative impact on springtails and earthworms (Collett 1999)

Advances in Forest Fire Research - Page 519 
or on richness or composition of beetle communities (Collett and Neumann 1995), but the effects of individual fires were quite variable. In contrast, two autumn fires over a five-year period produced a significant decrease in springtails, mites and earwigs and an increase in ant activity (Collett 1998). From studies based in Western Australian, Majer $(1980,1985)$ concluded that spring burning may be more detrimental to the soil-surface fauna than autumn burning. Some impacts however may be cumulative and take many years to manifest themselves. Examining the effects of seven fires over a 20 year period in sclerophyll forest in New South Wales, York (1999a) showed significantly lower ordinal diversity of surface-active and litter-inhabiting invertebrates in frequently burnt sites compared to unburnt sites.

With changing management practices involving the use of fire, concern has been recently expressed about the potential impacts of altered fire regimes on invertebrate diversity in both Mediterranean woodlands (Quartau 2009) and Australian temperate forests (New et al. 2010; York 2012). This paper utilises a long-term fire experiment to build on existing research; evaluating both the independent and combined effects of changed frequency and season of planned fire on litter-dwelling terrestrial invertebrates.

\section{Methods}

The study incorporates five areas (known locally as the 'Fire Effects Study Areas', FESA) within a 25 $\mathrm{km}$ radius in the Wombat State Forest, about $100 \mathrm{~km}$ north-west of Melbourne, Victoria, south-eastern Australia. The areas have an underlying geology of Ordovician sedimentary rock, and are at elevations ranging from 590 to $760 \mathrm{~m}$ above sea level. Topography varies from mostly flat (slopes $0-4^{\circ}$ ) to hills of low to moderate relief (slopes up to $21^{\circ}$ ). The climate is temperate, with annual rainfall in the range 814-901 mm, with the majority falling in winter and spring (Tolhurst and Flinn 1992). Native vegetation of the study areas is open to tall-open forest (tree heights 10 to $>30 \mathrm{~m}$, projective foliage cover 30-70\%; Specht 1981). Dominant trees are Messmate Stringybark Eucalyptus obliqua, Narrowleaf Peppermint E. radiata and Candlebark E. rubida. The understorey is characterised by a sparse shrub layer up to four metres in height (e.g. Acacia spp.), and ground layer of Austral Bracken (Pteridium esculentum) and native perennial grasses, forbs and rushes. Open to tall-open forests such as these are likely to be burnt more frequently under ongoing commitments to extensive use of prescribed fire on Victoria's public land (DSE 2012).

The study was established in 1985, and used a randomised block design involving a long-unburnt control (reference state) and four prescribed fire treatments randomly allocated within each of the five study areas (total of 25 treatment areas). The four fire treatments involved a factorial combination of two fire seasons (autumn or spring), and two fire frequencies (nominally every 3 or 10 years); that is, Autumn High-frequency (AH), Autumn Low-frequency (AL), Spring High-frequency (SH), and Spring Low-frequency (SL). Nominal prescribed fire intervals of three and ten years were chosen to represent, respectively, the shortest interval for sufficient recovery of surface fuels to carry a fire in these forests, and the likely return interval of prescribed fire based on local fire management practice. Prescribed fires in all treatments in this study were considered to be of low intensity (Tolhurst \& Flinn 1992). Mean inter-fire intervals ranged from 2.7-5.7 years in the High-frequency treatments, and 8.516 years in Low-frequency treatments (see Bennett et al. 2013 for further detail).

To sample topographic variability, three plots (ridge, slope and gully) were established in each of the five burn treatments in each of the five areas; giving 75 plots overall. In 2012, twenty $2000 \mathrm{~cm}^{3}$ samples of surface litter were systematically collected along 2 x $18 \mathrm{~m}$ orthogonal transects at each plot. Samples were bulked and sieved on site using a litter sifter (Upton \& Mantle 2010); with a single sample for each plot returned to the laboratory. Invertebrates were extracted over four days using Tullgren funnels at the University of Melbourne. Samples were stored in $70 \%$ alcohol and identified to Order or equivalent using a binocular dissecting microscope and appropriate taxonomic keys. 
Effects of prescribed fire treatments on invertebrate abundance were tested using Analysis of Variance (ANOVA) in Genstat $16^{\text {th }}$ Edition. A factorial plus added control model with area as a random factor, treatment as a fixed factor, and plot nested within treatment by area, was used to examine the overall effects of prescribed fire (Control versus Fire treatments), as well as the effects of prescribed fire season (Autumn versus Spring) and frequency (High versus Low), and their interactions.

\section{Results}

In total 276,314 individuals from 23 broad taxonomic groups were collected. A number of groups were poorly represented and/or unlikely to be effectively sampled using litter extraction, with data for 15 groups sufficient to undertake analyses (Table 1). Overall, there was a significant effect of fire frequency on total invertebrate abundance $(\mathrm{P}=0.009)$ with both Autumn High-frequency $(\mathrm{AH})$ and Spring High-frequency $(\mathrm{SH})$ treatments resulting in a substantial decline in mean invertebrate abundance (Table 1).

Table 1. Summary statistics of invertebrate abundance and ANOVA results for comparisons of five burning treatments (AL: Autumn Low-, AH: Autumn High-frequency; C: Unburnt; SL: Spring Low-, SH: Spring Highfrequency). B: significant burn treatment effect, $F$ : significant burn frequency effect $(P<0.05)$, ns: not significant. indicates groups poorly represented and/or unlikely to be effectively sampled using litter extraction (not tested).

\begin{tabular}{|c|c|c|c|c|c|c|}
\hline \multirow[t]{2}{*}{ Taxon } & \multicolumn{5}{|c|}{ Treatment (Abundance MEAN \pm S.E.) } & \multirow[t]{2}{*}{ ANOVA } \\
\hline & AL & $\mathrm{AH}$ & $\mathrm{C}$ & SL & $\mathrm{SH}$ & \\
\hline Mites & $2542.7 \pm 424.5$ & $1901.9 \pm 264.4$ & $2220.7 \pm 279.8$ & $2770.7 \pm 373.3$ & $1797.5 \pm 259.1$ & $\mathrm{~F}$ \\
\hline Amphipods & $28.7 \pm 11.7$ & $4.1 \pm 0.9$ & $27.7 \pm 5.8$ & $26.3 \pm 7.6$ & $9.1 \pm 3.5$ & $\mathrm{~F}$ \\
\hline Spiders & $66.9 \pm 11.4$ & $49.0 \pm 12.1$ & $77.7 \pm 7.2$ & $58.8 \pm 9.5$ & $48.1 \pm 8.0$ & $\mathrm{~B}, \mathrm{~F}$ \\
\hline Cockroaches & $9.1 \pm 1.5$ & $7.5 \pm 1.1$ & $7.0 \pm 1.1$ & $0.7 \pm 0.7$ & $6.8 \pm 0.8$ & ns \\
\hline Centipedes & $8.1 \pm 2.7$ & $8.7 \pm 1.9$ & $7.0 \pm 1.6$ & $9.8 \pm 1.8$ & $7.2 \pm 2.4$ & ns \\
\hline Beetles & $131.7 \pm 19.0$ & $97.5 \pm 11.7$ & $119.9 \pm 15.1$ & $133.7 \pm 13.9$ & $89.2 \pm 10.8$ & $\mathrm{~F}$ \\
\hline Springtails & $701.5 \pm 149.2$ & $340.2 \pm 50.1$ & $1507.3 \pm 358.6$ & $917.5 \pm 272.2$ & $566.3 \pm 122.4$ & B \\
\hline Earwigs & $1.4 \pm 0.6$ & $1.9 \pm 0.5$ & $0.3 \pm 0.2$ & $1.5 \pm 0.5$ & $1.1 \pm 0.4$ & - \\
\hline Diplopods & 25.415 .4 & $5.5 \pm 2.1$ & $21.7 \pm 9.1$ & $10.6 \pm 2.9$ & $5.0 \pm 2.0$ & ns \\
\hline Bristletails & 0.00 .0 & $0.1 \pm 0.1$ & $0.1 \pm 0.1$ & $0.0 \pm 0.0$ & $0.0 \pm 0.0$ & - \\
\hline Flies & $0.4 \pm 0.2$ & $0.6 \pm 0.2$ & $1.2 \pm 0.3$ & $1.1 \pm 0.3$ & $0.3 \pm 0.1$ & - \\
\hline Webspinners & $0.0 \pm 0.0$ & $0.0 \pm 0.0$ & $0.4 \pm 0.3$ & $0.0 \pm 0.0$ & $0.0 \pm 0.0$ & - \\
\hline Bugs & $18.1 \pm 2.3$ & $10.4 \pm 1.6$ & $17.8 \pm 2.9$ & $12.5 \pm 2.6$ & $12.7 \pm 1.9$ & ns \\
\hline Ants & $43.9 \pm 7.2$ & $41.7 \pm 7.9$ & $46.3 \pm 14.7$ & $48.3 \pm 6.2$ & $59.2 \pm 12.4$ & ns \\
\hline Wasps & $7.3 \pm 1.1$ & $8.4 \pm 1.1$ & $10.6 \pm 3.5$ & $8.9 \pm 1.5$ & $5.6 \pm 0.9$ & ns \\
\hline Woodlice & $13.9 \pm 3.1$ & $9.7 \pm 2.7$ & $23.7 \pm 4.0$ & $15.3 \pm 2.9$ & $7.9 \pm 3.4$ & B \\
\hline Larvae & $251.9 \pm 33.9$ & $182.0 \pm 23.9$ & $243.4 \pm 35.4$ & $267.3 \pm 31.9$ & $206.0 \pm 22.8$ & $\mathrm{~F}$ \\
\hline Velvet worms & $0.1 \pm 0.1$ & $0.0 \pm 0.0$ & $0.0 \pm 0.0$ & $0.1 \pm 0.1$ & $0.0 \pm 0.0$ & - \\
\hline Grasshoppers & $0.1 \pm 0.1$ & $0.1 \pm 0.1$ & $0.1 \pm 0.1$ & $0.1 \pm 0.1$ & $0.1 \pm 0.1$ & - \\
\hline Pseudoscorpions & $2.7 \pm 0.7$ & $3.2 \pm 0.9$ & $5.7 \pm 1.7$ & $6.0 \pm 2.1$ & $1.2 \pm 0.4$ & ns \\
\hline Barklice & $1.9 \pm 0.6$ & $0.1 \pm 0.3$ & $1.1 \pm 0.4$ & $1.9 \pm 0.5$ & $1.2 \pm 0.3$ & - \\
\hline Scorpions & $0.2 \pm 0.1$ & $0.3 \pm 0.2$ & $0.1 \pm 0.1$ & $0.2 \pm 0.1$ & $0.0 \pm 0.0$ & - \\
\hline Thrips & $73.9 \pm 19.4$ & $66.9 \pm 11.5$ & $100.6 \pm 26.2$ & $94.1 \pm 17.9$ & $98.5 \pm 19.9$ & ns \\
\hline Total & $3931.0 \pm 555.1$ & $2741.3 \pm 282.2$ & $4442.2 \pm 576.0$ & $4393.7 \pm 566.5$ & $2924.1 \pm 317.1$ & $\mathrm{~F}$ \\
\hline
\end{tabular}

When individual groups were considered, there were 3 basic patterns of response (Figure 1). Firstly, for seven groups (cockroaches, centipedes, diplopods, bugs, ants, wasps and barklice) there was no effect of fire treatments on their abundance at plots, suggesting that numbers of these groups were not 
impacted by fire in any season or at any frequency. Secondly, for three groups (spiders, springtails and woodlice) there was an effect of the burning treatment, suggesting fire (in any season and at any frequency) lowers their abundance. Thirdly, for five groups (mites, amphipods, spiders, beetles and larvae), there was a significant effect of fire frequency on their abundance. No season of fire effects were apparent for any group.
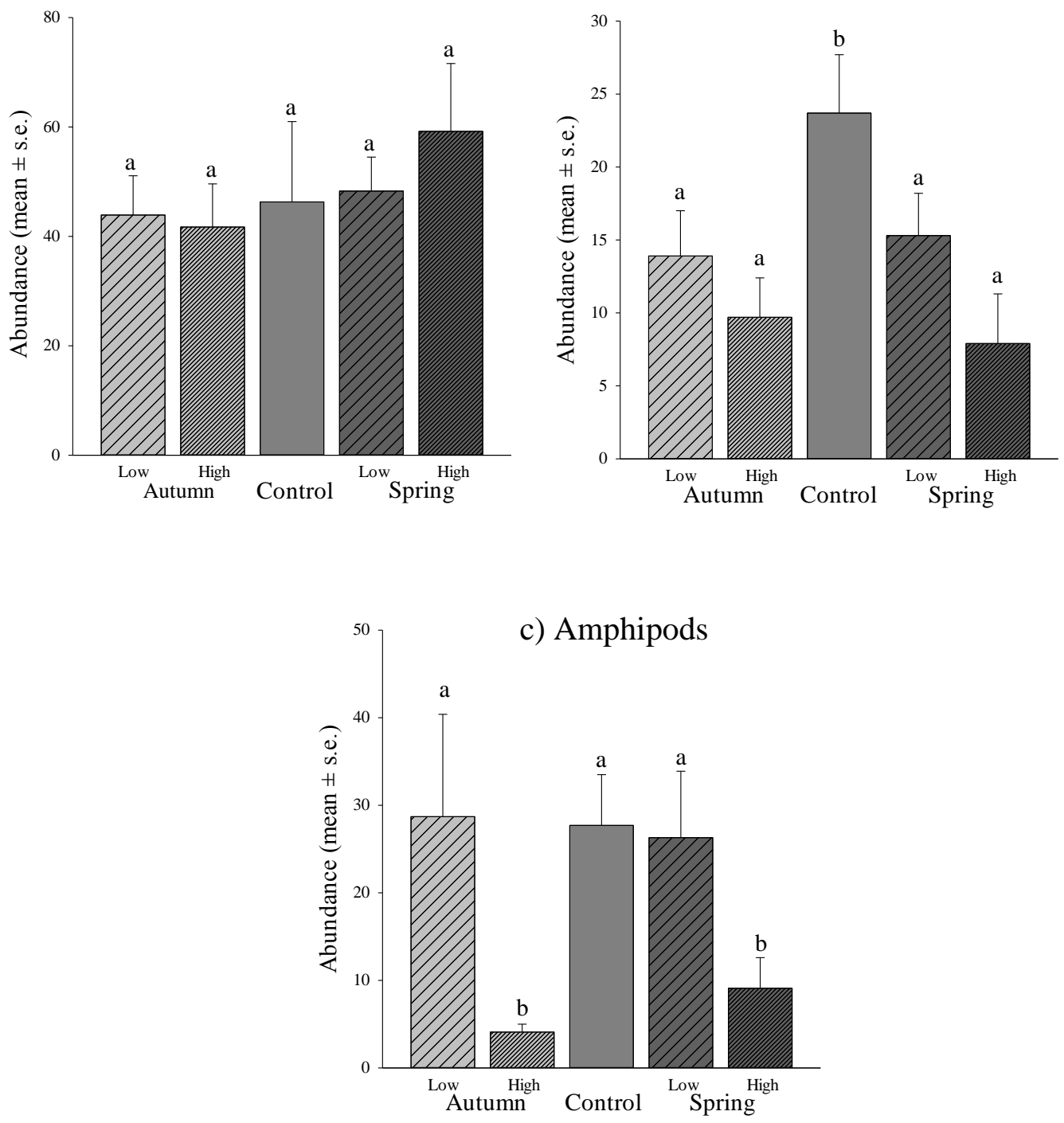

Figure 1. Examples of the three basic patterns of response. a) No effect of fire treatments on abundance e.g. ants. b) Significant effect of the burning treatment, irrespective of season and frequency e.g. woodlice. c) Significant effect of fire frequency e.g. amphipods. Columns with the same letters do not differ significantly, while those with different letters are significantly different in mean abundance (SNK post-hoc test). No season of fire effects were apparent for any group.

\section{Discussion}

Recent catastrophic wildfire events in Mediterranean-type ecosystems, including in Australia (Cameron et al. 2009), California (Keeley et al. 2009) and Greece (Pyne 2008), have led to increasing pressure on governments to mitigate fire risk (Teeter 2008; Teague et al. 2010). Fire prescriptions often target surface fuel loads in an attempt to reduce the intensity and spread of future wildfires (e.g. 
McArthur 1967; Gould et al. 2007). In Australian dry forest systems however, leaf litter can accumulate quickly, often reaching pre-fire levels within 3 years (Penman and York 2010). Maintaining low fuel levels in strategic locations, and/or increasing annual area burnt by prescribed fire, will inevitably lead to increases in the frequency of fire and changed season of burning, as land managers seek to maximise burning opportunities. While sclerophyll forests, woodlands and heaths are dominated by plant species with adaptive responses than enable them to survive periodic burning (Gill 1981; Noble and Slatyer 1981), the impact of fires on terrestrial invertebrates is poorly understood. Because low-intensity fires are often patchy in nature and invertebrates can seek shelter within the soil and in unburnt habitat refuges, it has been suggested (Majer 1980; Campbell and Tanton 1981; Abbott 1984) that periodic fires used for fuel management purposes have few long-term effects on most soil and litter invertebrates. Little is known, however, about the effects of the repeated use of fire over long time scales; particularly as frequent fires can reduce spatial and structural heterogeneity and could have long-term consequences for the survival of invertebrate populations (Collett et al. 1993).

This study investigated the impact of 30 years of low-intensity fire on a functionally important component of the forest biodiversity, litter-dwelling invertebrates. Soil- and litter-dwelling invertebrates play an important role in the breakdown of litter and soil organic matter; facilitating the decomposition process and contributing to nutrient availability (York et al. 2012). Results from this long-term fire study indicated three broad response patterns. Firstly, for seven groups (cockroaches, centipedes, diplopods, bugs, ants, wasps and barklice) there was no effect of fire treatments on their abundance at plots, suggesting that numbers of these groups were not impacted by fire in any season or at any frequency. York (1999a) found negative effects of frequent fire on cockroaches, centipedes and bugs, although the low numbers caught in that study warrant cautious interpretation. Secondly, for three groups (spiders, springtails and woodlice) there was an effect of the burning treatment, suggesting fire (in any season and at any frequency) lowers their abundance. Collett (1998) found that two autumn fires over a five-year period produced a significant decrease in springtail abundance, while York (1999a) reported reductions in the numbers of spiders, springtails and woodlice with frequent autumn fire. The third broad response identified concerned five groups (mites, amphipods, spiders, beetles and larvae), where there was a significant negative effect of fire frequency on their abundance. High fire frequency has previously been shown to reduce the numbers of these groups (York 1999a). It is of potential concern that high frequency fire (every $\sim 3$ years) significantly reduces the number of mites, amphipods, beetles and insect larvae. Amphipods (landhoppers) and larvae play major roles in litter fragmentation (Schowalter 2000) while many litter-dwelling beetles are associated with decomposer fungi (Lawrence and Slipinski 2013). This suggests a reduction in rates of decomposition and nutrient cycling with more frequent fire; which has implications for both rates of post-fire litter accumulation and forest health (see Brennan et al. 2009). The mechanisms underpinning these responses warrant further investigation, particularly in light of proposed increases in the amount of prescribed fire to be applied to these forest systems in coming years. It is most likely that frequent fire influences litter biomass and associated moisture levels (York 1999b; Penman and York 2010), and simplifies habitat structure. Several studies have reported the importance of litter depth and structure as a control of litter invertebrate composition (e.g. Uetz 1979; Michaels and McQuillan 1995). Because of this, litter fauna may take longer to recover after fire than the soil fauna (Majer 1984) and unburnt plants, logs and patches of litter become important refuges for fauna in burnt areas (Majer 1980; Whelan et al. 1980; Andrew et al. 2000). An interesting finding concerned the lack of a season of fire effect for any group. In earlier studies at this site Collett $(1993,1998,1999)$ and Collett and Neumann (1995) observed that effects of individual fires were quite variable, with outcomes for most groups more dependent on the severity of individual fires rather the season of burn. Koch and Majer (1980) have previously emphasised that an understanding of the phenology (seasonality) of invertebrate abundance and activity is needed to fully assess the potential impacts of burning. Future work on this 
project will target focal groups with an emphasis on understanding responses at the feeding guild or functional group level.

\section{References}

Abbott I (1984) Changes in the abundance and activity of certain soil and litter fauna in the jarrah forest of Western Australia after a moderate intensity wildfire. Australian Journal of Soil Research 22, 463-469.

Andrew N, Rodgerson L, York A (2000) Frequent fuel-reduction burning: the role of logs and associated leaf litter in the conservation of ant biodiversity. Austral Ecology 25, 99-107.

Attiwill PM, Adams MA (2013) Mega-fires, inquiries and politics in the eucalypt forests of Victoria, south-eastern Australia. Forest Ecology and Management. 294, 45-53.

Beattie AJ (1995) (Ed) 'Australia's Biodiversity. Living Wealth.' (Reed Books Australia)

Bennett LT, Aponte C, Tolhurst KG, Löw M, Baker TG (2013) Decreases in standing tree-based carbon stocks associated with repeated prescribed fires in a temperate mixed species eucalypt forest. Forest Ecology and Management 306, 243-255.

Bradstock RA, Hammill KA, Collins L, Price O (2010) Effects of weather, fuel and terrain on fire severity in topographically diverse landscapes of south-eastern Australia. Landscape Ecology 25, 607-619.

Brennan KEC, Christie FJ, York A (2009) Global climate change and litter decomposition: more frequent fire slows decomposition and increases the functional importance of invertebrate decomposers. Global Change Biology 15, 2958-2971.

Cameron PA, Mitra B, Fitzgerald M, Scheinkestel CD, Stripp A, Batey C, Niggemeyer L, Truesdale M, Holman P, Mehra R, Wasiak J, Cleland H (2009) Black Saturday: the immediate impact of the February 2009 bushfires in Victoria, Australia. The Medical Journal of Australia 191, 11-16.

Campbell AJ, Tanton MT (1981) Effect of fire on the invertebrate fauna of soil and litter of a eucalypt forest. In 'Fire and the Australian biota' (Eds AM Gill, RH Groves, IR Noble) pp. 215-242. (Australian Academy of Science, Canberra, Australia)

Cary GJ, Bradstock RA, Gill AM, Williams RJ (2012) Global change and fire regimes in Australia. In 'Flammable Australia. Fire regimes, biodiversity and ecosystems in a changing world' (Eds RA Bradstock, AM Gill, RJ Williams) pp.149-169 (CSIRO Publishing Australia)

Collett NG (1998) Effects of two short-rotation prescribed fires in autumn on surface-active arthropods in dry sclerophyll eucalypt forest of west-central Victoria. Forest Ecology and Management 107, 253-273.

Collett NG (1999) Effects of three short rotation prescribed fires in autumn on surface-active arthropods in dry sclerophyll eucalypt forest of west-central Victoria. Australian Forestry 62, 295306.

Collett NG (2003) Short and long-term effects of prescribed fires in autumn and spring on surface active arthropods in dry sclerophyll eucalypt forest of west-central Victoria. Forest Ecology and Management 182, 117-138.

Collett NG, Neumann FG (1995) Effects of two spring prescribed fires on epigeal Coleoptera in dry sclerophyll forest in Victoria, Australia. Forest Ecology and Management 6, 69-85.

Collett NG, Neumann FG, Tolhurst KG (1993) Effects of two short rotation prescribed fires in spring on surface-active arthropods and earthworms in dry sclerophyll eucalypt forest of west-central Victoria. Australian Forestry 56, 49-60.

DSE (2012) 'Code of Practice for Bushfire Management on Public Land'. Department of Sustainability and Environment (East Melbourne, Victoria, Australia)

Flannigan M, Cantin AS, de Groot WJ, Wotton M, Newbery A, Gowman LM (2013) Global wildland fire season severity in the 21st century. Forest Ecology and Management 294,54-61. 
Gill AM (1981) Adaptive responses of Australian vascular plant species to fires. In 'Fire and the Australian biota'. (Eds AM Gill, RH Groves, IR Noble) pp. 243-272. (Australian Academy of Science, Canberra)

Gould JS, McCaw WL, Cheney NP, Ellis PF, Matthews S (2007) Field Guide - Fuel Assessment and Fire Behaviour Prediction in Dry Eucalypt Forest. (Ensis-CSIRO: Canberra, ACT; and WA Department of Environment and Conservation: Perth, WA)

Keeley JE, Safford H, Fotheringham CJ, Franklin J, Moritz M (2009) The 2007 Southern California wildfires: lessons in complexity. Journal of Forestry 107, 287-296.

Koch LE and Majer JD (1980) A phenological investigation of various invertebrates in forest and woodland areas in the south-west of Western Australia. Journal of the Royal Society of Western Australia 63, 21-28.

Lawrence JF, Slipinski A (2013) 'Australia Beetles. Morphology, Classification and Keys. Volume 1'. (CSIRO Publishing, Australia)

Luke RH, McArthur AG (1978) 'Bushfires in Australia'. (Commonwealth of Australia)

Majer JD (1980) Report on a study of invertebrates in relation to the Kojonup Nature Reserve fire management plan. Bulletin Department of Biology Western Australian Institute of Technology 2, $1-22$.

Majer JD (1984) Ant return in rehabilitation mines - an indication of ecosystem resilience. In 'Medicos IV: Proceedings of the 4th International Conference on Mediterranean Ecosystems' (Ed B Dell) pp. 105-106. (Botany Department, University of Western Australia, Nedlands, Australia)

Majer JD (1985) Fire effects on invertebrate fauna of forest and woodland. In 'Symposium on Fire Ecology and Management in Western Australian Ecosystems'. (Ed JR Ford) pp. 103-106. (WAIT Environmental Studies Group Report No. 14. Western Australia)

McArthur AG (1967) Fire behaviour in eucalypt forests. Forestry and Timber Bureau, Department of National Development. (Canberra, ACT)

Michaels KF, McQuillan PB (1995) Impact of commercial forest management on geophilous carabid beetles (Coleoptera, Carabidae) in tall, wet Eucalyptus obliqua forest in southern Tasmania. Australian Journal of Ecology 20, 316-323.

New TR, Yen AL, Sands DPA, Greenslade P, Neville PJ, York A, Collett NJ (2010) Planned fires and invertebrate conservation in south east Australia. Journal of Insect Conservation 14, 567-574.

Noble IR and Slatyer RO (1981) Concepts and Models of Succession in Vascular Plant Communities Subject to Recurrent Fire. In 'Fire and the Australian Biota'. (Eds AM Gill, RH Groves, IR Noble) pp. 312-335. (Australian Academy of Science, Canberra)

Penman TD, Christie FJ, Andersen AN, Bradstock RA, Cary CJ, Henderson MK, Price O, Tran C, Wardle GM, Williams RJ, York A (2011) Prescribed burning: how can it work to conserve the things we value? International Journal of Wildland Fire 20, 721-733.

Penman TD, York A (2010) Climate and recent fire history affect fuel loads in Eucalyptus forests: Implications for fire management in a changing climate. Forest Ecology and Management 260, 1791-1797.

Pyne SJ (2008) Passing the torch: why the eons-old truce between humans and fire has burst into an age of megafires, and what can be done about it. The American Scholar 77, 22-32.

Quartau JA (2009) Preventative fire procedures in Mediterranean woods are destroying their insect biodiversity: a plea to the EU Governments. Journal of Insect Conservation 13, 267-270.

Raven PH, Yeates DK (2007) Australian biodiversity: threats for the present, opportunities for the future. Australian Journal of Entomology 46, 177-187.

Schowalter TD (2000) 'Insect Ecology. An Ecosystem Approach'. (Academic Press, New York)

Specht RL (1981) Foliage projective cover and standing biomass. In 'Vegetation Classification in Australia’. (Eds AN Gillson, DJ Anderson). Pp. 10-21. (CSIRO. Canberra, Australia) 
Stephens SL, McIver JD, Boerner REJ, Fettig CJ, Fontaine JB, Hartsough BR, Kennedy PL, Schwilk DW (2012) The Effects of Forest Fuel-Reduction Treatments in the United States. Bioscience, 62, 549-560.

Teague B, McLeod R, Pascoe S (2010) 'The 2009 Victorian Bushfires Final Report'. Parliament of Victoria. (Melbourne)

Teeter L (2008) Wildfire mitigation. Forest Policy and Economics 10, 341-343.

Tolhurst KG, Flinn D (1992) Ecological impacts of fuel reduction burning in dry sclerophyll forest: first progress report. Forest Research Section, Department of Conservation and Environment. (Kew, Victoria, Australia)

Uetz GW (1979) The influence of variation in litter habitats on spider communities. Oecologia 22, 373-385.

Upton MS, Mantle BL (2010) 'Methods for Collecting, Preserving and Studying Insects. 5th Edition'. Australian Entomological Society (Miscellaneous Publication No. 3, (Indooroopilly, Queensland)

Whelan RJ, Langedyk W, Pashby AS (1980) The effects of wildfire on arthropod populations in JarrahBanksia woodland. Western Australian Naturalist 14, 214-220.

York A (1999a) Long-term effects of frequent low-intensity burning on the abundance of litterdwelling invertebrates in coastal blackbutt forests of southeastern Australia. Journal of Insect Conservation 3,191-199.

York A (1999b) Long-term effects of repeated prescribed burning on forest invertebrates: management implications for the conservation of biodiversity. In 'Australia's Biodiversity - Responses to Fire'. Biodiversity Technical Series No. 1, pp. 181-266. (Environment Australia, Canberra)

York A (2012) Invertebrates and fire - Challenges and opportunities for conserving biodiversity. Proceedings of the Royal Society of Victoria 124, 47-55 (Melbourne, Australia)

York A, Bell TL, Weston C (2012) Fire regimes and soil-based ecological processes: implications for biodiversity. In 'Flammable Australia: Fire Regime, Biodiversity and Ecosystems in a Changing World'. (Eds RA Bradstock, RJ Williams, AM Gill) pp. 127-148 (CSIRO Publishing, Collingwood, Victoria) 